\title{
The Monitoring Role of Financial Analysts: An International Evidence
}

\author{
Ahmed Marhfor'1, Rachid Ghilal'2, Bouchra M'Zali ${ }^{3}$ \\ ${ }^{1}$ University of Quebec in Abitibi-Témiscamingue (UQAT), Rouyn-Noranda, Canada \\ ${ }^{2}$ University of Quebec in Rimouski (UQAR), Lévis, Canada \\ ${ }^{3}$ University of Quebec in Montréal (UQAM), Montréal, Canada \\ Email: Ahmed.Marhfor@uqat.ca, rachid ghilal@uqar.ca, mzali.bouchra@uqam.ca
}

Received 14 April 2015; accepted 10 May 2015; published 15 May 2015

Copyright (C) 2015 by authors and Scientific Research Publishing Inc.

This work is licensed under the Creative Commons Attribution International License (CC BY). http://creativecommons.org/licenses/by/4.0/

(c) (i) Open Access

\begin{abstract}
This study investigates whether high analyst coverage improves the quality of reported accounting numbers. Using conservatism in financial reporting as a proxy for the quality of reported earnings, we find evidence that analysts' activities are not positively associated with accounting conservatism. The findings indicate that firms choose less conservative accounting methods when they are covered by more analysts. They are consistent with the notion that analysts' activities do not substitute for other corporate governance mechanisms.
\end{abstract}

\section{Keywords}

Analyst Coverage, Accounting Conservatism, Corporate Governance, Earnings Recognition

\section{Introduction}

This paper examines whether more analyst coverage increases conservatism in financial reporting. Accounting conservatism refers to the idea that firm's losses are recognized (accelerated) as they are discovered, but gains are deferred until they are verified. We then empirically investigate the association between analyst activities and the incentives that may push managers to overstate firm's performance by withholding bad news and accelerating the release of good news. We conjecture that firms are less likely to disclose fraudulent financial information when analysts curb managerial incentives to accelerate good news recognition and delay bad news recognition. Our investigation is important because conservatism acts as a constraint for managers’ opportunism and optimism, reducing the probability of excess distribution to managers and current shareholders [1] [2]. Furthermore, accounting conservatism can also improve the efficiency of contracts written among conflicted parties [3] [4]. 
In fact, numerous studies suggest a positive association between conservatism and corporate governance quality [5] [6]. Consequently, the presence of a positive relation between analyst activities and accounting conservatism implies that analysts play an important role in financial reporting [7]. Our analysis should add new insights to the ongoing debate on the role played by financial analysts in capital markets. More precisely, we focus on analysts' corporate governance role. Analysts are known to use extensive accounting information to provide earnings forecasts. They are also supposed to be one of the most sophisticated users of firm's accounting information [8] [9]. Hence, analysts can monitor the management by scrutinizing financial statements and raising questions when they interact with firm's managers. This monitoring role may reduce managers' incentives to manipulate accounting numbers [7] [10].

This paper contributes to the literature in the following ways. First, we propose an intuitive approach that is applied for the first time to non US capital markets (21 developed and 23 emerging markets). To our best knowledge, the research design we rely on has been proposed only for US markets. Second, our analysis extends the limited research on the monitoring role of analysts by using a large sample of non US firms over the period prior to the financial crisis. It is worth mentioning that most studies in the literature provide either US evidence or limited international evidence.

We find that high analyst following leads firms to slow the recognition of bad news into earnings. We also document that more analyst coverage has no impact on the sensitivity of earnings to good news. Our evidence suggests that firms do not adopt more conservatism accounting when they are followed by a large number of analysts. Hence, contrary to other studies, our findings show that analysts are not a substitute for effective corporate governance mechanisms.

\section{Previous Research Work and Empirical Methodology}

\subsection{The Monitoring Role of Analysts}

The research on analysts' monitoring role is limited in the literature. In 2007, Knyazeva [10] shows that analyst coverage constrains earnings management. In the same line of reasoning, Yu [11] finds a negative relation between analyst coverage and earnings management. As for Dyck et al. [12], they show that analysts are more effective than auditors and US Securities and Exchange Commission in detecting frauds. In 2014, Bo and Wan [13] find that analysts' short-term earnings forecasts exhibit similar conservatism as accounting earnings, indicating that analysts do understand accounting conservatism. On the other hand, another strand of research questions the monitoring role of analysts. For instance, some papers findings suggest that analysts bias their predictions toward a more optimistic view to generate more investment banking business and trading commissions [14] [15] [16]. Analysts are also reluctant to issue unfavorable investment information because they fear losing access to management [15]. In 2010, Pae and Thornton [17] find that analysts' forecasts error differs among firms with different levels of accounting conservatism, indicating that analysts do not fully incorporate the implications of conservative reporting. Louis et al. [18] also provide evidence which suggests that analysts do not adjust their earnings forecasts for conservatism.

\subsection{Accounting Conservatism Estimation}

We base our empirical analysis on the premise that accounting conservatism helps investors monitor firm's managers [1] [5] [19]. Firm's investors demand timely recognition of bad news into earnings because managers have incentives to recognize gains earlier and defer losses for private gain [20] [21]. We argue that high conservatism reporting should curb managers' tendency to hide bad news from investors and overstate earnings. Furthermore, firms that report more conservatively are more likely to discontinue projects that become unprofitable [22]. To investigate the association between analysts and conservatism, we use the asymmetric recognition of economic gains and losses as our proxy for conservatism. More specifically, we propose to examine the impact of analysts' activities on the speed of good news recognition and on the incremental speed of bad news recognition. Following Bushman and Piotroski [23], we estimate the following models:

$$
\begin{aligned}
& \mathrm{NI}_{\mathrm{i}, \mathrm{t}}=\beta_{0}+\beta_{1} \text { return }_{\mathrm{i}, \mathrm{t}}+\beta_{2} \text { Dummy }+\beta_{3} \text { Dummy } \text { return }_{\mathrm{i}, \mathrm{t}}+\text { controls }+\varepsilon_{\mathrm{i}, \mathrm{t}} \\
\mathrm{NI}_{\mathrm{i}, \mathrm{t}}= & \beta_{0}+\beta_{1} \text { return }_{\mathrm{i}, \mathrm{t}}+\beta_{2} \text { Dummy } \beta_{3} \text { Dummy } \operatorname{return}_{\mathrm{i}, \mathrm{t}}+\beta_{4} \log \left(1+\mathrm{NA}_{\mathrm{i}, \mathrm{t}}\right) \\
+ & \beta_{5} \log \left(1+\mathrm{NA}_{\mathrm{i}, \mathrm{t}}\right) * \operatorname{return}_{\mathrm{i}, \mathrm{t}}+\beta_{6} \text { Dummy }^{\operatorname{return}_{\mathrm{i}, \mathrm{t}}} * \log \left(1+\mathrm{NA}_{\mathrm{i}, \mathrm{t}}\right)+\text { controls }+\varepsilon_{\mathrm{i}, \mathrm{t}}
\end{aligned}
$$


where NI is accounting earnings (Net income divided by market value of equity) and Dummy is an indicator variable set equal to one if firm's return is negative, and zero otherwise. In Equations (1) and (2), firm's return can be considered as a proxy for news recognition. Negative (positive) returns are a proxy for bad (good) news. Return $_{\mathrm{i}, \mathrm{t}}$ is adjusted share price at the end of year $(\mathrm{t})+$ adjusted dividends for year $(\mathrm{t})$; all divided by the adjusted share price at the end of year (t-1). In the case of Equation (1), $\beta_{1}$ captures the speed of good news recognition into earnings and $\beta_{3}$ is the incremental speed of bad news recognition into earnings relative to the speed of good recognition [23]. When $\beta_{3}=0$, there is no difference between the speed of good news recognition and bad news recognition. On the other hand, a positive and significant $\beta_{3}$ means that the speed of bad news recognition is faster than the speed of good news recognition for firm (i), suggesting a more conservative reporting approach.

In Equation (2), we augment Equation (1) with analyst following. $\mathrm{NA}_{\mathrm{i}, \mathrm{t}}$ is the number of analysts that issued one-year-ahead earnings forecasts for firm (i) during year ( $\mathrm{t}$ ). As suggested by Bushman and Piotroski [23], the interpretation of coefficients in Equation (2) is more complex. In fact, if $\beta_{5}=0$, we can say that the sensitivity of earnings to good news is the same for firms with high analyst coverage and firms with low analysts coverage. If $\beta_{5}<0$, the speed of good news recognition is slower for firms with high analyst coverage. In other words, financial analysts constrain management incentives to accelerate the release of good news. In the same line of reasoning, when $\beta_{6}=0$, we can say that there is no difference between the speed of good news recognition and bad news recognition for firms with high or low analyst coverage. However, if $\beta_{6}>0$, then the incremental speed of bad news recognition relative to good news recognition is faster for firms with high analyst coverage. This means that analysts' activities can curb managers' tendency to hide or delay the release of bad news.

\section{Data and Empirical Results}

The sample construction starts with non US firms originating from 44 countries over the period 1990-2006. As suggested earlier, our purpose is to examine the role played by financial analysts outside the US and during the years before the financial crisis. For each firm, we collect its accounting earnings, stock returns, and a variety of control variables from Worldscope. To be consistent with the literature, we exclude financial firms from our sample. To mitigate the influence of extreme values, regression results are robust to outliers (variables are winsorized at $1 \%$ in each tail). We obtain analyst coverage data from the Institutional Brokers' Estimate System (I/B/E/S). When I/B/E/S does not report an analyst forecast for firm (i) in year ( $t$ ), we assume that the number of analysts following the firm is zero as suggested by Piotroski and Roulstone [8]. Therefore, our main analysis includes firms with no earnings forecasts. In our robustness checks, we care to exclude such firms.

Table 1 provides descriptive statistics of the main variables used in the study. We present the mean, median, 5th percentile, 95th percentile, standard deviation and the number of observations. Given the large proportion of firms with zero analyst coverage, we perform our tests both with and without these firms. A potential concern is that our findings can be influenced by such observations. In fact, as suggested by Chan and Hameed [9], the absence of firm's earnings forecasts could mean that there was no analyst coverage or that the data for the firm were not captured by I/B/E/S. The average number of analysts (NA) covering our sample is 1.899 (median of 0). On the other hand, when we drop observations with zero analyst coverage, the average number (NAbis) becomes 5.721 (median of 3). Furthermore, to account for differences in the role played by analysts across countries because of differences in institutions, we also propose to add to our main framework a variety of institutional variables linked to economic and political environment.

Table 2 summarizes the results from estimates of Equation (2). Columns 1, 2, 5 and 6 present coefficients from regressions using observations with zero analyst coverage, while in columns 3, 4, 7 and 8 we repeat the same analysis without observations with zero analyst coverage. We control for political risk in our regressions (columns 2, 4, 6 and 8) because Bushman and Piotroski [23] show that political institutions can impact accounting conservatism. Our control variables capture different aspects of political risk (corruption, level of democracy, political freedom, and lack of transparency). To quantify the level of corruption (CO), we use the Heritage foundation index. A higher score of our corruption index means that risks connected to corruption are low. The scores of such index are derived primarily from Transparency International Corruption Index (CPI). Furthermore, to proxy for level of democracy and political freedom for each country, we rely on the political rights index. Countries whose ratings average 1 to 2.5 are considered to be free, 3 to 5 partly free, and 5.5 to 7 not free. Finally, we measure the general information environment using an index of the press freedom. Greater scores of our press freedom index (no free press) suggest that asymmetric information problems are severe in the country. 
Table 1. Descriptive statistics.

\begin{tabular}{ccccccc}
\hline \multirow{2}{*}{ Variables } & \multicolumn{7}{c}{ Descriptive statistics of the main variables } \\
\cline { 2 - 7 } & Mean & Median & 5th Pctl. & 95th Pctl. & Std dev & N \\
\hline Accounting Earnings (NI) & 0.0622 & 0.135 & -0.535 & 0.697 & 31.227 & 87,721 \\
Return (R) & 1.4413 & 1.0526 & 0.544 & 2.199 & 2.248 & 89,646 \\
Number of Analysts (NA) & 1.899 & 0 & 0 & 11 & 4.567 & 170,784 \\
NAbis & 5.721 & 3 & 1 & 19 & 6.4 & 56,693 \\
Size & 11.692 & 11.607 & 8.628 & 15.168 & 1.965 & 94,048 \\
Market-to-Book (M/B) & 2.589 & 1.317 & 0.1604 & 6.643 & 4.167 & 94,576 \\
Sales Growth (SG) & 0.375 & 0.074 & -0.307 & 0.948 & 10.791 & 93,173 \\
Corruption (CO) & 62.031 & 67 & 26 & 92 & 24.024 & 168,583 \\
Press Freedom (PF) & 33.019 & 23 & 10 & 81 & 22.542 & 161,172 \\
Political Rights (PR) & 2.25 & 1 & 1 & 7 & 1.974 & 161,172 \\
Gross Domestic Product(GDP) & 1890.82 & 21,691 & 558 & 37867 & 1371.4 & 162,756
\end{tabular}

This table presents descriptive statistics for variables used in our analysis. We use a large sample of firms originating from 21 developed markets and 23 emerging markets over the period 1990-2006. For each variable, we provide the mean, median, 5th percentile, 95th percentile, standard deviation and the number of observations.

Table 2. Analyst coverage and accounting conservatism: main results. This table presents coefficients and test statistics from estimations of Equation (2).

\begin{tabular}{|c|c|c|c|c|c|c|c|c|}
\hline Variables & Model 1 & Model 2 & Model 3 & Model 4 & Model 5 & Model 6 & Model 7 & Model 8 \\
\hline Intercept & $-0.3085^{* * *}$ & -0.0983 & $-0.6358^{* * *}$ & $-0.4426^{* * *}$ & $-0.6255^{* * *}$ & $-0.2410^{* * *}$ & $-0.9611^{* * *}$ & $-0.5631^{* * *}$ \\
\hline Return & 0.0001 & 0.0001 & 0.0051 & 0.0044 & 0.0001 & 0.0002 & 0.0034 & 0.0036 \\
\hline Dummy & $-0.1208^{* * *}$ & $-0.1245^{* * *}$ & $-0.1576^{* * *}$ & $-0.1613^{* * *}$ & $-0.1342^{* * *}$ & $0.1328^{* * *}$ & $-0.1720^{* * *}$ & $-0.1774^{* * *}$ \\
\hline Dummy*return & $0.1207^{* * * *}$ & $0.1284^{* * *}$ & $0.1352^{* * *}$ & $0.1353^{* * *}$ & $0.1294^{* * *}$ & $0.1403^{* * *}$ & $0.1522^{* * * *}$ & $0.1515^{* * * *}$ \\
\hline $\log (1+N A)$ & $-0.0290^{* * *}$ & $-0.0211^{* * *}$ & -0.0178 & -0.0090 & -0.0025 & 0.0054 & -0.0109 & 0.0028 \\
\hline $\log (1+N A) *$ return & 0.0035 & 0.0034 & 0.0023 & 0.0016 & 0.0004 & -0.0001 & -0.0007 & -0.0012 \\
\hline $\begin{array}{c}\text { Dummy } * \log (1+N A) \\
* \text { return }\end{array}$ & $-0.0352^{* * *}$ & $-0.0368^{* * *}$ & $-0.0216^{*}$ & -0.0193 & $-0.0293^{* * *}$ & $-0.0334^{* * *}$ & -0.0181 & -0.0128 \\
\hline Size & $0.0591^{* * *}$ & $0.0661^{* * *}$ & $0.0971^{* * *}$ & $0.1069^{* * *}$ & $0.0858^{* * *}$ & $0.0968^{* * *}$ & $0.1267^{* * *}$ & $0.1357^{* * *}$ \\
\hline $\mathrm{M} / \mathrm{B}$ & 0.0004 & 0.0006 & 0.0007 & 0.0008 & 0.0002 & 0.0003 & 0.0003 & 0.0005 \\
\hline Sales Growth & $-0.0001^{*}$ & $-0.0001^{*}$ & 0.0003 & 0.0001 & $-0.0001^{*}$ & $-0.0001^{*}$ & -0.0002 & -0.0001 \\
\hline GDP & -0.0005 & -0.0007 & $-0.002^{* * *}$ & $-0.0001^{*}$ & $-0.0001^{*}$ & $-0.0001^{*}$ & $-0.004^{* * *}$ & $-0.002^{* * *}$ \\
\hline Press Freedom & & $0.003^{* * *}$ & & 0.0022 & & $0.0026^{* * *}$ & & 0.0012 \\
\hline Political rights & & $-0.0965^{* * *}$ & & $-0.0775^{* * *}$ & & $-0.1109^{* * *}$ & & $-0.0846^{* * *}$ \\
\hline Corruption & & $-0.0029^{* * *}$ & & $-0.0039^{* * * *}$ & & $-0.0057^{* * *}$ & & $-0.0069^{* * *}$ \\
\hline $\mathrm{R}^{2}$ & 0.0392 & 0.0621 & 0.0508 & 0.0729 & 0.0488 & 0.0740 & 0.0526 & 0.0794 \\
\hline $\mathrm{N}$ & 72,902 & 68,598 & 42,444 & 40,610 & 72,902 & 68,598 & 42,444 & 40,610 \\
\hline
\end{tabular}

Standard errors are adjusted for both heteroskedasticity and clustering at the firm level. One, two or three asterisks denote significance at the $10 \%$, $5 \%$ and $1 \%$ levels, respectively.

We also include firm size, M/B ratio, sales growth, and GDP per capita to control for differences in accounting earnings arising from these factors. In addition, for models 1, 2, 3 and 4, we estimate Equation (2) using both firm and year fixed effects. In the remaining models, we estimate Equation (2) by including country random effects. These estimations reveal two important results. First, the sensitivity of earnings to bad news is signifi- 
cantly lower for firms with high analyst coverage ( $\beta_{6}$ of Equation (2) is negative and significant at $1 \%$ in 4 of 8 specifications reported in Table 2). Second, there is no relationship between analysts activities and the speed of good news recognition ( $\beta_{5}$ of Equation (2) is not significant in all specifications). The first finding is consistent with the idea that analysts do not curb managers' incentives to defer the recognition of losses. The second result suggests that analysts' activities are not associated with lower good news sensitivity. Hence, firms followed by a high number of analysts have a tendency to maximize firm's performance by delaying bad news recognition. Contrary to previous studies, our findings indicate that analysts are not a substitute for effective corporate governance mechanisms.

We also consider the fact that analysts' decision to cover a firm is endogenous. For instance, analysts could self-select the firms to follow based on their financial situation, potential investment-banking transactions, and other factors. To deal with this concern, we propose the Heckman (1979) two-step estimation. In the first step, we model the choice of covering a firm through a probit model. Following prior studies [8] [9], we consider that analyst activities are affected by the following variables: firm size, return volatility, earnings volatility, trading volume and firm's ownership.

Then, we propose the following model:

$$
\begin{gathered}
U_{i}=W_{i} \gamma+v_{i} \quad \text { Coverage }_{\mathrm{i}}=1 \\
\text { if } U_{i}>0 ; 0 \text { otherwise }
\end{gathered}
$$

where $U_{i}$ is an unobserved latent variable (utility of analyst $i$ to cover a firm) and $W_{i}$ is a set of variables that affect the decision of analysts to cover a firm. We don't observe $U_{i}$. All we observe is a dichotomous variable Coverage $_{i}$ with the value of one if the firm has analysts that follow its activities $\left(U_{i}>0\right)$ and 0 otherwise.

When we correct for selection bias (results not tabulated), the negative association we found between analyst coverage and the speed of bad news recognition is no longer significant. Furthermore, good news-earnings sensitivity is still not affected by analyst coverage. Hence, loss recognition does not increase with analyst coverage and gains recognition does not slow, either. Based on our findings, managers do not appear to adjust their financing reporting (more conservative reporting) in response to more analyst coverage.

\section{Conclusions}

Despite the potentially useful role of security analysts, the recent financial crisis (2008) has severely shaken investors' confidence in analysts' activities. In this paper, we have examined the impact of analyst coverage on accounting conservatism. The purpose is to test whether analysts can effectively monitor firm's managers by reducing their ability to manipulate accounting numbers (differ the release of bad news and accelerate the release of good news). We find that analysts' activities do not impact the sensitivity of earnings to good and bad news, indicating that analyst coverage is insufficient to generate conservative reporting. Hence, our findings suggest that analyst coverage is not positively associated with accounting conservatism.

This paper sheds some light on the role played by financial analysts before the financial crisis. In fact, our results suggest that the "additional monitoring" provided by analysts does not encourage timely loss recognition. As suggested by Kim and Zhang [24] (p. 3, 2015): "The managerial tendency to conceal bad news from outside investors engenders crash risk. This is because the asymmetric disclosure behavior of managers leads to stockpiling within a firm of negative information unknown to outside investors. When the accumulated bad news reaches a certain tipping point or when the managerial incentive for hiding bad news collapses, the large amount of negative information will suddenly and immediately be released to the market, leading to an abrupt decline in stock price or a crash". We conjecture that the lack of monitoring by analysts may have affected, in part, the efficiency of capital markets around the world and led to the financial crisis.

Our study has its limitations. First, we do not cover the post-crisis period. Future research could investigate whether our findings are still relevant in the post-crisis period. Second, we may not capture all components of conservatism because our proxy only covers one dimension of accounting conservatism (asymmetric recognition of gains and losses). Hence, other avenues of measuring accounting conservatism should be examined in the future. This will offer further validation of the actual findings.

\section{References}

[1] Watts, R. (2003) Conservatism in Accounting Part I: Explanations and Implications. Accounting Horizons, 17, $207-221$. http://dx.doi.org/10.2308/acch.2003.17.3.207 
[2] Francis, R.N., Harrats, S., Mattingly, J. and Olsen, L. (2013) The Relation between Accounting Conservatism and Corporate Social Performance: An Empirical Investigation. Business and Society Review, 118, 193-222. http://dx.doi.org/10.1111/basr.12008

[3] Watts, R. (1993) A Proposal for Research on Conservatism. Working Paper, University of Rochester, Rochester.

[4] Zhang, J.Y. (2008) The Contracting Benefits of Accounting Conservatism to Lenders and Borrowers. Journal of Accounting and Economics, 45, 27-54. http://dx.doi.org/10.1016/j.jacceco.2007.06.002

[5] Ahmed, A.S. and Duellman, S. (2007) Accounting Conservatism and Board of Director Characteristics: An Empirical Analysis. Journal of Accounting and Economics, 43, 411-437. http://dx.doi.org/10.1016/j.jacceco.2007.01.005

[6] García Lara, J.M., García Osma, B. and Penalva, F. (2009) Accounting Conservatism and Corporate Governance. Review of Accounting Studies, 14, 161-201. http://dx.doi.org/10.1007/s11142-007-9060-1

[7] Sun, J. and Liu, G.P. (2011) The Effect of Analyst Coverage on Accounting Conservatism. Managerial Finance, 37, 520. http://dx.doi.org/10.1108/03074351111092111

[8] Piotroski, J.D. and Roulstone, D.T. (2004) The Influence of Analysts, Institutional Investors, and Insiders on the Incorporation of Market, Industry, and Firm-Specific Information into Stock Prices. The Accounting Review, 79, 11191151. http://dx.doi.org/10.2308/accr.2004.79.4.1119

[9] Chan, K. and Hameed, A. (2006) Stock Price Synchronicity and Analyst Coverage in Emerging Markets. Journal of Financial Economics, 80, 115-147. http://dx.doi.org/10.1016/j.jfineco.2005.03.010

[10] Knyazeva, D. (2007) Corporate Governance, Analyst Following, and Firm Behavior. Working Paper, New York University, New York.

[11] Yu, F. (2008) Analyst Coverage and Earnings Management. Journal of Financial Economics, 88, 245-271. http://dx.doi.org/10.1016/j.jfineco.2007.05.008

[12] Dyck, A., Morse, A. and Zingales, L. (2006) Who Blows the Whistle on Corporate Fraud? Working Paper, University of Chicago, Chicago.

[13] Bo, O. and Wan, H. (2014) Do Analysts Understand Conservatism? Accounting and Finance Research, 3, 1-8.

[14] Doukas, J., Kim, C.F. and Pantzalis, C. (2008) Do Analysts Influence Corporate Financing and Investment? Financial Management, 37, 303-339. http://dx.doi.org/10.1111/j.1755-053X.2008.00014.X

[15] McNichols, M.F. and O’Brien, P.C. (1997) Self-Selection and Analysts Coverage. Journal of Accounting Research, 35, 167-199. http://dx.doi.org/10.2307/2491460

[16] Lin, H.W. and McNichols, M.F. (1998) Underwriting Relationships, Analysts’ Earnings Forecasts and Investment Recommendations. Journal of Accounting and Economics, 25, 107-127. http://dx.doi.org/10.1016/S0165-4101(98)00016-0

[17] Pae, J. and Thornton, D. (1999) International Differences in Timeliness, Conservatism and Analysts' Forecast Inefficiency. Asia-Pacific Journal of Financial Studies, 39, 171-197. http://dx.doi.org/10.1111/j.2041-6156.2010.00008.x

[18] Louis, H., Lys, T. and Sun, A.X. (2008) Conservatism and Analyst Earnings Forecast Bias. Working Paper, Pennsylvania State University, University Park.

[19] Ball, R. and Shivakumar, L. (2005) Earnings Quality in UK Private Firms: Comparative Loss Recognition. Journal of Accounting and Economics, 39, 83-128. http://dx.doi.org/10.1016/j.jacceco.2004.04.001

[20] Chen, S., Chen, X., Cheng, Q. and Hutton, A. (2009) Accounting Conservatism and Large Shareholders: An Empirical Analysis. Working Paper, University of Wisconsin, Madison.

[21] La Fond, R. and Watts, R. (2008) The Information Role of Conservatism. The Accounting Review, 83, 447-478. http://dx.doi.org/10.2308/accr.2008.83.2.447

[22] Francis, J. and Martin, X. (2010) Acquisition Profitability and Timely Loss Recognition. Journal of Accounting and Economics, 49, 161-178. http://dx.doi.org/10.1016/j.jacceco.2009.09.003

[23] Bushman, R.M. and Piotroski, D. (2006) Financial Reporting Incentives for Conservatism Accounting: The Influence of Legal and Political Institutions. Journal of Accounting and Economics, 42, 107-148. http://dx.doi.org/10.1016/j.jacceco.2005.10.005

[24] Kim, J.B. and Zhang, L.D. (2015) Accounting Conservatism and Stock Price Crash Risk: Firm-Level Evidence. Contemporary Accounting Research, Published Online. http://dx.doi.org/10.1111/1911-3846.12112 